\title{
The ladybird beetle Harmonia axyridis (Coleoptera: Coccinellidae) as a possible predator of grape phylloxera Daktulosphaira vitifoliae (Hemiptera: Phylloxeridae)
}

\author{
SusanNe KÖGEL ${ }^{1}$, MANuela SCHIELER ${ }^{1,2}$ and Christoph HOFFMANN ${ }^{1}$ \\ ${ }^{1}$ Julius Kühn-Institut, Federal Research Center for Cultivated Plants, Institute for Plant Protection in Fruit Crops and Viticulture, \\ Geilweilerhof, D-76833 Siebeldingen, Germany; e-mail: Susanne.koegel@jki.bund.de \\ ${ }^{2}$ Trier University, FB VI, Department of Biogeography, D-54286 Trier, Germany
}

Key words. Coleoptera, Coccinellidae, Harmonia axyridis, Hemiptera, Phylloxeridae, Daktulosphaira vitifoliae, grapevine, Vitis vinifera, consumption

\begin{abstract}
The ladybird beetle Harmonia axyridis (Pallas 1773) has been used for biological control in several countries. However, it became invasive in some of those countries. Coccinella septempunctata (Linné 1758) is a native species in Europe. It feeds mainly on aphids and can be very abundant. As far as is known there are no effective natural enemies of the grape phylloxera Daktulosphaira vitifoliae (Fitch 1855) in Europe. The potential of the above two ladybird species for reducing the abundance of the grapevine pest $D$. vitifoliae has not been previously investigated. In this study, the consumption and developmental parameters of $H$. axyridis and $C$. septempunctata fed on $D$. vitifoliae were determined in the laboratory. In a field trial, the occurrence of $H$. axyridis on grapevines with or without leaf galls of $D$. vitifoliae was compared. In contrast to C. septempunctata, H. axyridis was able to complete its development using $D$. vitifoliae as a source of food. In addition, adult $H$. axyridis consumed significantly more $D$. vitifoliae eggs than C. septempunctata. Within $24 \mathrm{~h} \mathrm{H}$. axyridis consumed up to 1400 eggs of D. vitifoliae. However, based on the fitness parameters "developmental time", percentage "survival" and "adult weight", this diet was less suitable for H. axyridis than the eggs of Ephestia kuehniella. During field observations over a period of two years $H$. axyridis was repeatedly observed feeding on grape phylloxera leaf galls, which indicates that $H$. axyridis uses grape phylloxera as prey. $H$. axyridis was significantly more abundant on leaves with leaf galls of $D$. vitifoliae than on leaves without galls. C. septempunctata was rarely found on grape leaves with or without leaf galls. These results indicate that overall $H$. axyridis, unlike $C$. septempunctata, is a predator of $D$. vitifoliae and could potentially reduce grape phylloxera numbers in vineyards.
\end{abstract}

\section{INTRODUCTION}

The Multicoloured Asian ladybird beetle, Harmonia axyridis (Pallas 1773) (Coleoptera: Coccinellidae), was introduced from Asia into North America and Europe as a biocontrol agent (Ferran et al., 1996; Koch, 2003). It has become an invasive species in these countries. In Central Europe 96 Coccinellidae species are described as native (Klausnitzer \& Klausnitzer, 1997) of which the abundant seven-spot ladybird beetle Coccinella septempunctata (Linné 1758) (Coleoptera: Coccinellidae) is one.

There are numerous studies on consumption rates and life table parameters, such as fecundity, developmental time, percentage mortality and fresh weight of adults, of both these species of ladybird when fed different species of aphid (Michaud, 2000; Specty et al., 2003; Seko \& Miura, 2008; Finlayson et al., 2009; Xue et al., 2009). Life tables of Coccinellidae can vary depending on the diet and can be used as an indicator of the fitness of these insects (Kalushkov \& Hodek, 2004).

When aphids become scarce in autumn, $H$. axyridis is able to feed on damaged fruit, like grapes (Galvan et al., 2006), and as a consequence may be accidentally processed together with the grapes during harvest. Release of their hemolymph into the must gives the wine a specific taste called "ladybird taint" or "ladybug taint" (Galvan et al., 2007; Pickering et al., 2007; Kögel et al., 2012b). Therefore $H$. axyridis is mainly considered to be a pest in viticulture. In addition to $H$. axyridis, $C$. septempunctata can also cause this specific off-flavour (Botezatu \& Pickering, 2010; Kögel et al., 2012a). Both species can be found in and around vineyards.

Grape phylloxera Daktulosphaira vitifoliae (Fitch 1855 ) is a gall forming insect infesting roots and leaves of grapevine (Vitis vinifera, American species of Vitis and hybrids). This pest is native to North America and invasive in other regions such as Europe. In the beginning of the $20^{\text {th }}$ century, feeding of Phylloxera on nongrafted $V$. vinifera caused considerable damage in Europe. The problem was solved by grafting $V$. vinifera onto American (non-vinifera) rootstocks tolerant to $D$. vitifoliae. Recently, $D$. vitifoliae has been repeatedly found on wild rootstocks in the vicinity of vineyards in Germany (Hoffmann, 2011). During a period of three consecutive years (2009-2011) we observed $H$. axyridis feeding inside the leaf galls of grape phylloxera. We also observed male and female $H$. axyridis copulating on vine leaves with galls, which might indicate that Phylloxera galls represent a suitable food resource for the reproduction of this ladybeetle.

In this context we decided to address the following topics: 

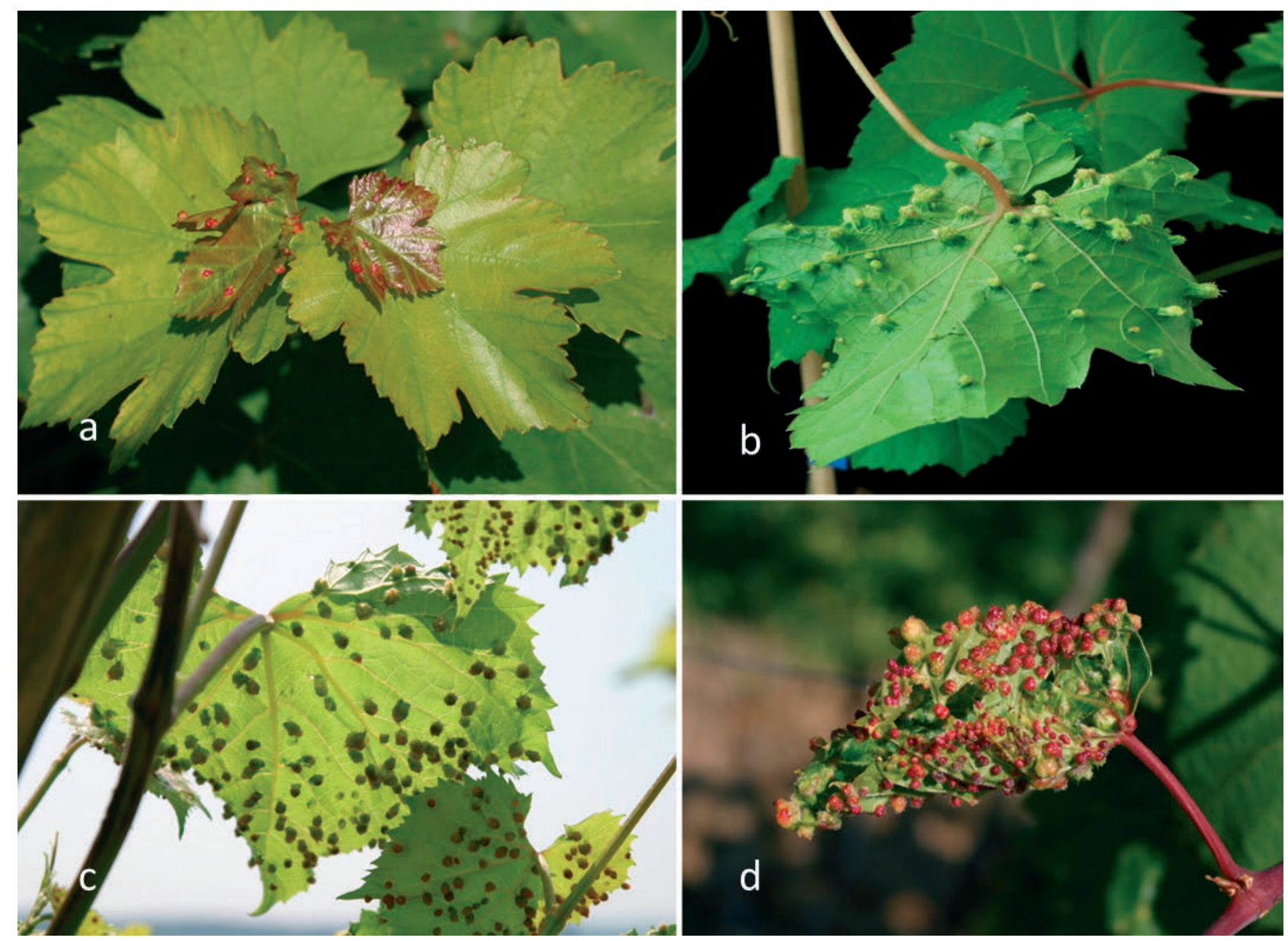

Fig. 1a-d. Levels of infestation of grapevine leaves by grape phylloxera: category 1-2 (a), category 3-5 (b), category 6-7 (c) and category 8-9 (d).

- Is $H$. axyridis able to develop from egg to adult when feeding exclusively on grape phylloxera?

- How do the rates of consumption of grape phylloxera by $H$. axyridis compare with those of $C$. septempunctata?

- Is the feeding of $H$. axyridis on phylloxera leaf galls in vineyards a random phenomenon or of common occurrence?

With these questions in mind, we tried to assess the rates at which $H$. axyridis and $C$. septempunctata consumed the eggs of $D$. vitifoliae under defined laboratory conditions. In addition, developmental parameters of the two species feeding on grapevine leaves, with and without phylloxera leaf galls, were determined and compared to those recorded when fed on a diet of E. kuehniella eggs. Furthermore, the association of $H$. axyridis with the leaf galls produced by grape phylloxera was investigated in the field in 2010 and 2011. We used $C$. septempunctata as a control species in this study because it is the second most common species of ladybird in German vineyards and can also be found hiding in grapes at harvest time.

The combined results of the laboratory and field experiments should provide information on whether $H$. axyridis is an important predator of $D$. vitifoliae.

\section{MATERIAL AND METHODS}

\section{Laboratory study}

Prey suitability

The neonate larvae came from laboratory cultures kept in a controlled climate chamber at the Julius Kühn-Institute (JKI), Dossenheim, Germany. One neonate larva of either H. axyridis or C. septempunctata was placed in each Petri dish (diameter $=$ $15 \mathrm{~cm})$. In each dish there were two leaves of Vitis sp. infested with leaf galls of $D$. vitifoliae (cat. 9; see Material and Methods field trial). In addition, there were 2 control dishes with: (i) two leaves of Vitis sp. without leaf galls and (ii) eggs of E. kuehniella $(500 \mathrm{mg})$.

Water was supplied via a cotton wool pad. The Petri dishes were placed in a controlled climate chamber $\left(16 \mathrm{~L}: 8 \mathrm{D}, 24^{\circ} \mathrm{C}\right.$, $70-80 \% \mathrm{RH})$. Every $24 \mathrm{~h}$ the larval stages and pupae were monitored and their developmental times and mortality recorded until the adults emerged from the pupae. Every $48 \mathrm{~h}$ the leaves and E. kuehniella eggs were replaced by fresh material. The newly emerged adults were weighed and their sex determined. This was replicated twenty times for each species.

Egg consumption by adult ladybird beetles

Adults of $C$. septempunctata and $H$. axyridis were collected in the field $24 \mathrm{~h}$ before they were used in this experiment. They were collected at Siebeldingen (Germany) from a field planted with field beans (Vicia faba). These beetles were kept in plastic containers in a climate chamber $\left(16 \mathrm{~L}: 8 \mathrm{D}, 24^{\circ} \mathrm{C}, 70-80 \% \mathrm{RH}\right)$ without food for $24 \mathrm{~h}$. 
TABLE 1. Developmental time of the larval instars and pupae, fresh mass of newly emerged adults, prey suitability (SL) and percentage mortality of the ladybird beetles $H$. axyridis and C. septempunctata reared on Vitis vinifera leaves with and without leaf galls of $D$. vitifoliae, or on a diet of E. kuehniella eggs in Petri dishes in a climate chamber $\left(16 \mathrm{D}: 8 \mathrm{D}, 24^{\circ} \mathrm{C}, 70-80 \% \mathrm{RH}\right)$.

\begin{tabular}{|c|c|c|c|c|c|c|c|c|c|c|}
\hline \multirow{3}{*}{ Food given } & \multirow{3}{*}{$\begin{array}{l}\text { Species } \\
(\mathrm{N} \text { at begin } \\
=20)\end{array}$} & \multicolumn{6}{|c|}{ Mean \pm SD developmental time [d] } & \multirow{3}{*}{$\begin{array}{c}\text { Adult } \\
\text { weight } \\
{[\mathrm{mg}] \pm \mathrm{SD}}\end{array}$} & \multirow{3}{*}{$\mathrm{SL} \pm \mathrm{SD}$} & \multirow{3}{*}{$\begin{array}{c}\text { Mortality } \\
{[\%]}\end{array}$} \\
\hline & & \multicolumn{4}{|c|}{ Instars } & \multirow{2}{*}{ Pupa } & \multirow{2}{*}{ Total } & & & \\
\hline & & $1^{\text {st }}$ & $2^{\text {nd }}$ & $3^{\mathrm{d}}$ & $4^{\text {th }}$ & & & & & \\
\hline \multirow{2}{*}{$\begin{array}{l}\text { Leaves with } \\
\text { leaf galls of } \\
D \text {. vitifoliae }\end{array}$} & H. axyridis & $2.0 \pm 0.0$ & $3.9 \pm 2.3$ & $3.8 \pm 1.5$ & $7.8 \pm 1.4$ & $5.8 \pm 2.3$ & $\begin{array}{c}20.5 \pm \\
3.9^{* a}\end{array}$ & $\begin{array}{c}14.8 \pm \\
3.9^{* \mathrm{a}}\end{array}$ & $\begin{array}{l}0.6^{* \mathrm{a}} \\
\pm 0.2\end{array}$ & $53.3 * \mathrm{~A} * \mathrm{a}$ \\
\hline & $\begin{array}{c}C . \\
\text { septempunctata }\end{array}$ & $1.8 \pm 0.4$ & $1.0 \pm 0.0$ & - & - & - & - & - & - & $100 * \mathrm{~B} * \mathrm{a}$ \\
\hline \multirow{2}{*}{$\begin{array}{l}\text { Leaves without } \\
\text { leaf galls }\end{array}$} & H. axyridis & $2.0 \pm 0.0$ & - & - & - & - & - & - & - & $100 * \mathrm{~A}$ \\
\hline & $\begin{array}{c}C . \\
\text { septempunctata }\end{array}$ & $1.0 \pm 0.0$ & - & - & - & - & - & - & - & $100 * \mathrm{~A}$ \\
\hline \multirow{2}{*}{$\begin{array}{l}\text { E. kuehniella } \\
\text { eggs }\end{array}$} & H. axyridis & $1.0 \pm 0.0$ & $1.9 \pm 0.9$ & $2.0 \pm 0.6$ & $4.8 \pm 0.6$ & $4.8 \pm 0.5$ & $\begin{array}{c}14.7 \pm \\
0.7^{* \mathrm{~A} * \mathrm{~b}}\end{array}$ & $\begin{array}{c}24.7 * \mathrm{~A} * \mathrm{~b} \\
\pm 2.5\end{array}$ & $\begin{array}{c}2.5^{* \mathrm{~A} * \mathrm{~b}} \\
\pm 0.4\end{array}$ & $13.3^{* \mathrm{~b}}$ \\
\hline & $\begin{array}{c}C . \\
\text { septempunctata }\end{array}$ & $1.3 \pm 0.5$ & $2.1 \pm 0.7$ & $2.5 \pm 0.5$ & $5.0 \pm 0.6$ & $4.9 \pm 0.7$ & $\begin{array}{c}15.9 \pm \\
1.2^{* \mathrm{~A}}\end{array}$ & $\begin{array}{c}26.5^{* \mathrm{~A}} \\
\pm 1.4\end{array}$ & $\begin{array}{l}2.4^{* \mathrm{~A}} \\
\pm 0.3\end{array}$ & $20.0^{* \mathrm{~b}}$ \\
\hline
\end{tabular}

*A $;{ }^{\mathrm{B}}$ indicates significant differences between the two species (Mann-Whitney-U-test, $\mathrm{p}<0.001$ )

${ }^{* a},{ }^{* b}$ indicates significant differences between the diet groups within one species (Mann-Whitney-U-test, $\mathrm{p}<0.05$ )

Grapevine leaves infested with leaf galls of $D$. vitifoliae were collected from a vineyard at the Julius Kühn-Institute in Siebeldingen (Germany). In the laboratory, the leaf galls were dissected with a razor blade and the eggs were collected using the washing method described by Hill \& Schlamp (1984). Eggs were then transferred, using a paint brush, on to a $\varnothing 9 \mathrm{~cm}$ filter paper in a Petri dish along with one adult ladybird beetle, which had been previously weighed and sexed, and then the dish was put in the climate chamber. Each adult beetle of $H$. axyridis and C. septempunctata was provided with either 100, 200 or 500 eggs. Because of differences in their feeding behaviour, H. axyridis was additionally also provided with $1000,2000,3000$ or 4000 eggs/beetle and C. septempunctata 10,20 or 50 eggs/beetle. After $24 \mathrm{~h}$ the remaining eggs were counted. Hatched nymphs of $D$. vitifoliae were counted as eggs. There were ten replicates of each treatment.

\section{Field study}

Field trials were carried out in the same vineyard near Siebeldingen in 2010 and 2011 from July through to the end of September. The vineyard was planted with grapevines of different genotypes (interspecific crossings) and vines were not sprayed during the course of this study. Grapevines were marked and sampled as follows: 20 infested vines (including several categories $\geq$ cat. $3-5$ ) and 20 vines not infested with leaf galls of $D$. vitifoliae (cat. 1-2) in 2010 and the same design was used with 50 vines each in 2011. For example in 2011, 50 grapevines were marked as uninfested (cat. 1-2), 12 were marked as cat. $3-5,19$ as cat. $6-7$ and 19 as cat. 8-9. The grapevines were of several genotypes in both years and no grapevine was used twice.

The levels of infestation with grape phylloxera of the selected vines was ranked, based on the guidelines of the German Federal Plant Variety Office ("Bundessortenamt"; Anonymous, 1989), into one of 9 categories (cat.):

Cat. $1-2=$ no or just a few leaf galls, probably no eggs (Fig. 1a)

Cat. 3-5 = few leaf galls (Fig. 1b)

Cat. $6-7=$ big and many leaf galls (Fig. 1c)

Cat. $8-9=$ big and numerous leaf galls (Fig. 1d)

All marked vines were searched visually weekly for adults of $H$. axyridis and $C$. septempunctata. In addition, all marked vines were checked for mildew, mites or other possible sources of food for H. axyridis.

\section{Data analysis}

Statistical analyses were performed using SPSS statistics 17 (IBM). Differences in consumption rate and developmental parameters were analyzed using Mann-Whitney-U-tests. Differences between the categories $1-2,3-5,6-7$ and $8-9$ in the field trials were analyzed using Kruskal-Wallis-H-tests. The level of significance was set at $\alpha=0.05$. To check the suitability of $D$. vitifoliae as food for the ladybird beetles under laboratory conditions the prey suitability parameter (SL) was calculated as SL $=\mathrm{m} / \mathrm{t}(\mathrm{m}=$ fresh mass of newly emerged adults in $\mathrm{mg} ; \mathrm{t}=$ days from hatching of the $1^{\text {st }}$ instar to pupation) (Ungerova et al., 2010).

\section{RESULTS}

\section{Laboratory study}

Prey suitability

Unlike $C$. septempunctata, $H$. axyridis was able to complete its life cycle from the $1^{\text {st }}$ instar to adult when provided with only grapevine leaves with leaf galls (Table $1)$. The percentage mortality of $H$. axyridis was $53 \%$, while all the $C$. septempunctata died in the $1^{\text {st }}$ or $2^{\text {nd }}$ instar. The percentage mortality of the two species differed significantly $(\mathrm{p}<0.001)$.

Both larvae and adult $H$. axyridis were observed feeding on leaf galls. For this the width and structure of the opening of the gall on the upper leaf surface is likely to be a critical factor. This opening is protected by hairs, which bend outwards. Both 1st and 2nd instar larvae were observed within the leaf galls and are therefore apparently small enough to pass through the opening. Older immature stages as well as adult beetles were commonly observed trying to remove the hairs, either by pushing them aside with their pronotum or by biting them.

Attempts to rear either H. axyridis or C. septempunctata on grapevine leaves without galls resulted in 100\% of them dying in the first two instars. 


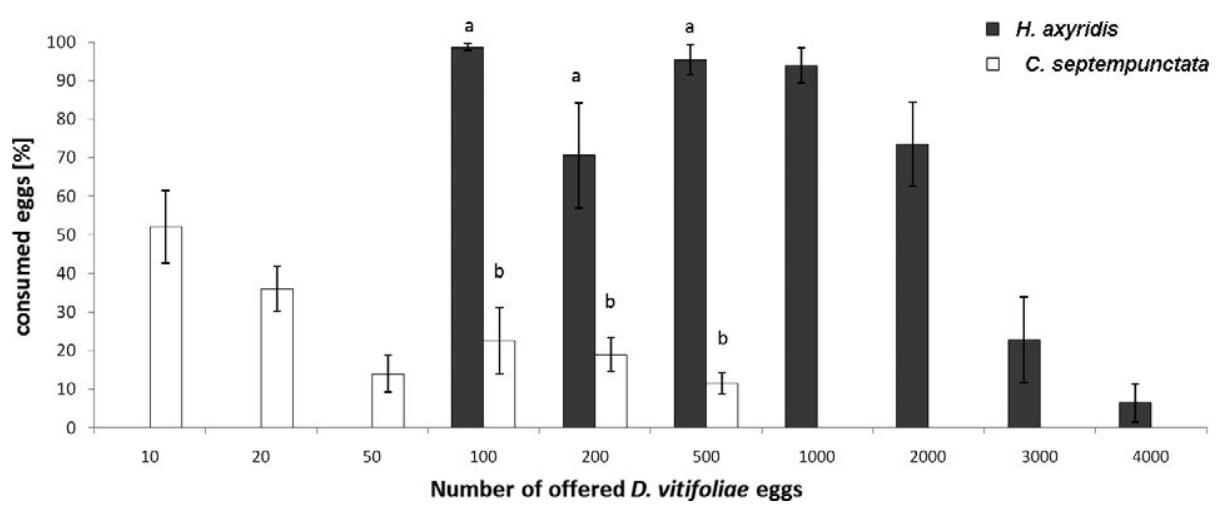

Fig. 2. Consumption (mean \%) of D. vitifoliae eggs by H. axyridis (black) and C. septempunctata (white) after $24 \mathrm{~h}$ in relation to egg density $(100,200,500,1000,2000,3000,4000$ eggs for $H$. axyridis and 10, 20, 50, 100, 200, 500 eggs for C. septempunctata), $\mathrm{n}=10$. Error bars represent \pm SE. Small letters indicate significant differences in egg consumption $(\alpha=0.05$; $\mathrm{p}<0.05$; MannWhitney-U test).

When provided with a diet of E. kuehniella eggs both H. axyridis and C. septempunctata were able to complete their life cycle. There were significant differences in the developmental parameters of the H. axyridis fed on leaf galls compared with those fed E. kuehniella eggs ( $<$ 0.05; Table 1).

Egg consumption by adult ladybird beetles

$H$. axyridis consumed significantly more grape phylloxera eggs/ $24 \mathrm{~h}$ than C. septempunctata $(\mathrm{n}=10: 100$ eggs: $\mathrm{p}<0.001 ; 200$ eggs: $\mathrm{p}<0.05 ; 500$ eggs: $\mathrm{p}<0.001$, Fig. 2). For example a total of $71 \pm 14 \%$ (mean \pm SE) of the 200 eggs was consumed by $H$. axyridis after $24 \mathrm{~h}$, whereas only $19 \pm 4 \%$ was consumed by $C$. septempunctata.

While $H$. axyridis consumed $94 \pm 15 \%$ of the 1000 eggs provided within $24 \mathrm{~h}$, this decreased to only $23 \pm 11 \%$ when 3000 eggs were provided (Fig. 2).

The consumption of eggs by $C$. septempunctata was always markedly lower. In the treatment with ten eggs a mean reduction of $52 \pm 9 \%$ was recorded after $24 \mathrm{~h}$ and

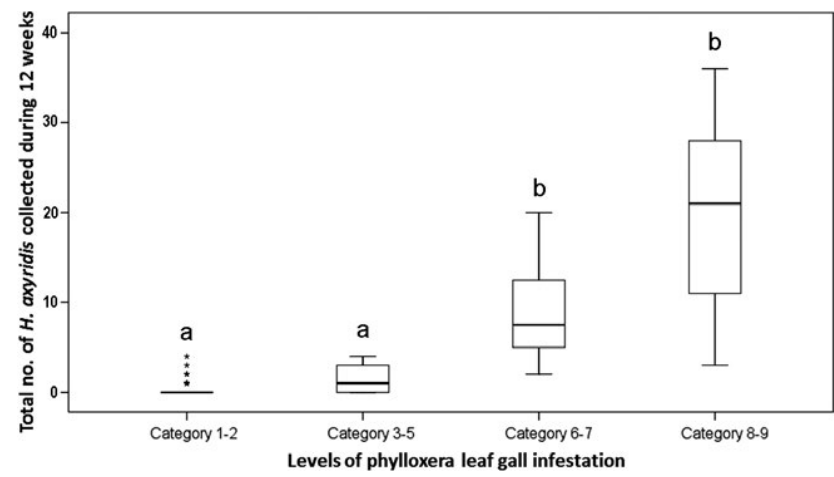

Fig. 3. Number of $H$. axyridis observed between July and September 2011 on grapevines with different levels of infestation with leaf galls of $D$. vitifoliae (50 grapevines for category $1-2,12$ for 3-5, 19 for 6-7 and 19 for 8-9). See Material \& Methods for description of categories. Horizontal lines indicate medians, boxes represent the interquartile ranges and the standard deviations. Outliers are indicated by an asterisk. Small letters indicate significant differences between the four categories $(\alpha=0.05 ; \mathrm{p}<0.05$; Kruskal-Wallis-H-test). they only consumed $12 \pm 3 \%$ of the maximum number of eggs offered (500 eggs; Fig. 2).

\section{Field study}

The total numbers of adult $H$. axyridis on grapevines with and without leaf galls was significantly different $(\mathrm{p}<$ $0.001)$ in both years. In 2010, an average of $2.95 \pm 0.88$ (mean $\pm \mathrm{SE}$ ) adult $H$. axyridis per vine (in total 59) was recorded on vines with leaf galls category $\geq 3-5$. In 2011, $11.42 \pm 1.40$ adults per plant (in total 575) were counted on the same categories. In contrast, only $0.25 \pm 0.08$ (in total 5) and $0.38 \pm 0.12$ (in total 19) adults of H. axyridis per plant were found on vines with leaf gall category $1-2$ in 2010 and 2011, respectively.

The numbers of individuals of $H$. axyridis on leaf galls were significantly different in both years on vines of category $1-2$; cat. $3-5$; cat. $6-7$ and cat. $8-9(\mathrm{p}<0.05 ; 2011$ : Fig. 3). The highest abundance of $H$. axyridis was recorded from the end of July until mid-August, when the Phylloxera infestation reached a maximum. Leaf galls were big and abundant during this period. In the following weeks, the number of adults on leaves with leaf galls decreased (Fig. 4).

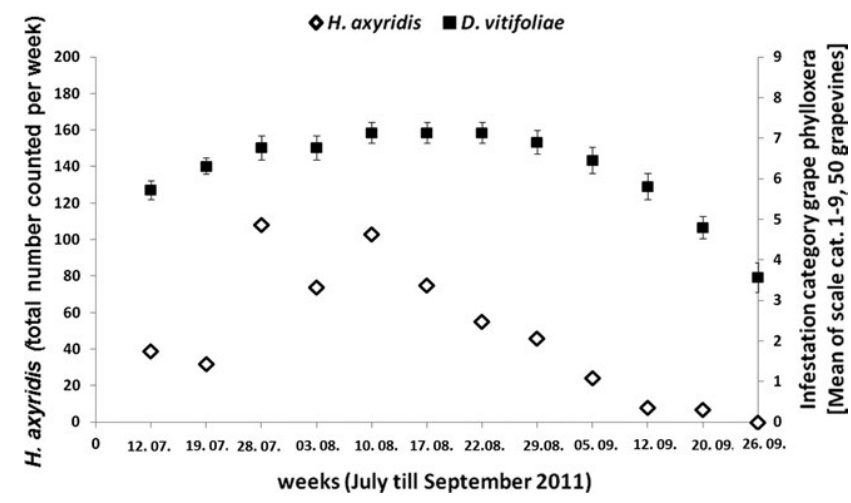

Fig. 4. Counts (total number counted per week) of $H$. axyridis (white rhombus) on grapevines ( $\mathrm{n}=50$, cat. $\geq 3-5)$ infested with leaf galls of $D$. vitifoliae together with mean number of galls per leaf (mean and SE; ranked in categories 1 to 9; black squares). 
There was no correlation between the abundance of $H$. axyridis and the occurrence of mildew, mites or aphids on grapevines. During our observations, we recorded only 9 adults of $C$. septempunctata on grapevine leaves in 2011 and 2 adults in 2010, respectively. Due to the low abundance of this species it was not possible to determine whether it showed a preference for leaves infested with grape phylloxera.

\section{DISCUSSION}

The laboratory study showed that $H$. axyridis is able to complete its life cycle by feeding exclusively on $D$. vitifoliae. There was no other suitable food on grapevine leaves because all the larvae on leaves without galls died. However, the developmental time, percentage survival and fresh weight of newly emerged adults (Hodek 1973; Kalushkov \& Hodek, 2004; Pervez \& Omkar, 2006) indicate that the quality of $D$. vitifoliae as prey for this ladybird is poor. The measure of prey suitability (SL) recorded in the laboratory was 0.6 , which is very low compared to the 2.5 recorded when fed a diet of E. kuehniella eggs. The prey suitability of aphids like Aphis philadelphi, A. fabae or Dysaphis plantaginea for this ladybird is $>1.5$ (Ungerova et al., 2010). Even $\mathrm{A}$. sambuci has a prey suitability of 1.1 (Ungerova et al., 2010), although it is known to be a non-optimum food for $H$. axyridis and even toxic for some other ladybird beetles (Omkar \& Srivastava, 2003; Nedved \& Salvucci, 2008). However, when comparing developmental parameters it is important that the rearing conditions, like photoperiod and type of rearing boxes, are identical. For example, developmental time may be influenced by photoperiod or even the type of rearing box (Ungerova et al., 2010; Reznik \& Vaghina, 2011). The rearing conditions used by Ungerova et al. (2010) are similar to those used in this study.

Body weight of adult $H$. axyridis reared on $D$. vitifoliae was significantly lower than that of those fed on E. kuehniella eggs. Furthermore, the developmental time was significantly longer and percentage survival less (Table 1). The results obtained in this study for $H$. axyridis fed $E$. kuehniella eggs correspond well with previously published data on developmental time (14-17 d), body weight $(25-35 \mathrm{mg})$ and percentage survival $(>80 \%)$ (Abdel-Salam et al., 1997; Specty et al., 2003; Kögel et al., 2012c). Small adults of Adalia bipunctata have a lower fecundity and their eggs are less fertile than those of large adults (Hodek, 1973). This might be the same for H. axyridis.

Unlike $H$. axyrids, $C$. septempunctata was not able to develop on a diet of grape phylloxera as all the larvae that hatched on leaves with and without leaf galls died.

$H$. axyridis is able to complete its development feeding on Toxoptera citricida and Aphis spiraecola, but C. septempunctata cannot (Michaud, 2000). This and the above results may indicate that $H$. axyridis is more of a generalist predator than $C$. septempunctata. The pronounced polyphagy of $H$. axyridis and its use of a wide range of aphids is already well known (Koch, 2003; Pervez \&
Omkar, 2005; Berkvens et al., 2010). When reared on an optimum diet, such as E. kuehniella eggs, the body weight, developmental time and percentage mortality of $C$. septempunctata were comparable to those of $H$. axyridis (Table 1 ). It is also likely that $H$. axyridis only feeds and reproduces on grape phylloxera in late summer.

Adults of $H$. axyridis consumed more $D$. vitifoliae eggs per unit time than those of $C$. septempunctata. Overall, $H$. axyridis is also well known to be more voracious in terms of the range of different species of prey it will eat than $C$. septempunctata (Lucas et al., 1997; Finlayson et al., 2009).

At first glance the laboratory results indicate that $H$. axyridis could be a predator of $D$. vitifoliae. However, laboratory results have a limited value for determining the extent of predation under field conditions (O'Neil, 1997). In our study, significantly higher numbers of $H$. axyridis were observed in the field on grapevines with leaf galls than on grapevines without them. This observation might indicate that this ladybird beetle uses one or more life stages of $D$. vitifoliae as prey in the field. Due to no observed site effects and no plant protection, other possible food resources for $H$. axyridis are considered as widely equivalent in our trial (see trial design). Also we observed $H$. axyridis attacking galls in the field. In addition, the occurrence of $H$. axyridis was not correlated with the presence of mildew and/or mites on the grapevines. C. septempunctata was rarely found on grape vines infested with grape phylloxera possibly because it is not an attractive prey for the seven-spot-ladybeetle.

The maximum numbers of $H$. axyridis on grapevines with leaf galls was observed at the beginning of August, which is the time when the $D$. vitifoliae leaf galls are most abundant and the majority contain eggs (Forneck \& Huber, 2008). Subsequently, grape phylloxera migrates to the roots and few eggs remain in leaf galls and/or the infested leaves are shed (Bessin, 2003; Powell, 2008). This possibly accounts for the decline in the abundance of $H$. axyridis on leaf galls in autumn. Also aphids on other crops (sunflower, maize or sudan grass) are abundant at this time (unpublished data).

$H$. axyridis has the potential to pollute wine with so called "ladybird taint". The risk is greatest when $H$. axyridis is present in vineyards in late summer when the grapes are ripe. Possibly the beetles migrate to and feed on the ripening grapes when nymphs of $D$. vitifoliae become scarce in September. This did not occur to any great extent in 2010 and 2011 but this needs to be studied in the future.

In conclusion, in the field the invasive $H$. axyridis is a possible predator of $D$. vitifoliae. Even though grape phylloxera is not the optimum food for $H$. axyridis, it may serve as a source of food if other food is rare or lacking in late summer.

ACKNOWLEDGEMENTS. This work was supported by a grant from the "Forschungsring Deutscher Weinbau" (FDW). We are grateful to M. Paulus, C. Emmerling and S. Lötters of Trier University FB VI Geography/Biogeography for coopera- 
tion. We thank J. Gross, M. Fischer and M. Maixner, Julius Kühn-Institut, for improvements.

\section{REFERENCES}

Abdel-Salam A.H., Ellington J.J., El-Adl M.A., Abou ElNaga A.M. \& GHanim A.A. 1997: Longevity and fecundity of Harmonia axyridis adults reared on an artificial diet and pink bollworm eggs. In: Proc. 1st National Conf. of Applied Using of Natural Enemies for Controlling Insect and Mite Pests, Mansoura, 4-5 March, 1997, Vol. 1. pp. 50-57.

Anonymous 1989: Richtlinie des Bundessortenamtes für die Durchführung der Prüfungen von Rebsorten auf die Anfälligkeit für die Reblaus. German Federal Plant Variety Office.

Berkvens N., Landuyt C., Deforce K., Berkvens D., Tirry L. \& De CleRCQ P. 2010: Alternative foods for the multicoloured Asian lady beetle Harmonia axyridis (Coleoptera: Coccinellidae). - Eur. J. Entomol. 107: 189-195.

Bessin R. 2003: Grape Phylloxera. Entomology Factsheet 222, University of Kentucky, College of Agriculture, http://www. ca.uky.edu/entomology/entfacts/entfactpdf/ef222.pdf

Botezatu A. \& Pickering G.J. 2010: Ladybug (Coccinellidae) taint in wine. In Reynolds A.G.: Understanding and Managing Wine Quality and Safety. Woodhead, Cambridge, pp. 418-429.

Ferran A., Niknam H., Kabiri F., Picart J., DeHerve C., Brun J., IPERTI G. \& LAPCHIN L. 1996: The use of Harmonia axyridis larvae (Coleoptera: Coccinellidae) against Macrosiphum rosae (Hemiptera: Sternorrhyncha: Aphididae) on rose bushes. - Eur. J. Entomol. 93: 59-67.

Finlayson C., Alyokhin A., Gross S. \& Porter E. 2009: Differential consumption of four aphid species by four lady beetle species. - J. Insect Sci. 10: 1-10.

FORNECK A. \& HUBER L. 2008: (A)sexual reproduction - a review of life cycles of grape phylloxera, Daktulosphaira vitifoliae. - Entomol. Exp. Appl. 131: 1-10.

Galvan T.L., Burkness E.C. \& Hutchison W.D. 2006: Influence of berry injury on infestations of the multicolored Asian lady beetle in wine grapes. - Plant Health Progress doi:10.1094/PHP-2006-1003-01-RS

Galvan T.L., Burkness E.C., Vickers Z., Stenberg P., MansFIELD A.K. \& HutchisON W.D. 2007: Sensory-based action threshold for multicolored Asian lady beetle-related taint in winegrapes. - Am. J. Enol. Viticult. 58: 518-522.

Hill G. \& Schlamp H. 1984: Der Einsatz der Waschmethode zur Ermittlung des Raubmilbenbesatzes auf Rebblättern. Die Weinwissenschaft 4: 255-262.

Hodek I. 1973: Biology of Coccinellidae. Academia, Prague, $260 \mathrm{pp}$.

HofFMANN C. 2011: Reblaus-Fachgespräch beim Institut für Pflanzenschutz in Obst- und Weinbau des JKI in Siebeldingen. - J. Cultivated Plants 63: 340-343.

KALUSHKov P. \& HodeK I. 2004: The effects of thirteen species of aphids on some life history parameters of the ladybird Coccinella septempunctata. - Biocontrol 49: 21-32.

Koch R.L. 2003: The multicolored Asian lady beetle, Harmonia axyridis: A review of its biology, uses in biological control, and non-target impacts. - J. Insect Sci. 3/32: 1-16.

Kögel S., Hoffmann C., Gross J. \& Ulrich D. 2012a: Diversity and frequencies of methoxypyrazines in hemolymph of Harmonia axyridis and Coccinella septempunctata and their influence on the taste of wine. - Eur. Food Res. Technol. 234: 399-404.
Kögel S., Gross J. \& Hoffmann C. 2012b: Sensory detection thresholds of "ladybird taint" in "Riesling" and "Pinot noir" under different fermentation and processing conditions. Vitis 51: 27-32.

Kögel S., Eben A., Hoffmann C. \& Gross J. 2012c: The influence of diet on fecundity, immune defense and 2-isopropyl-3methoxypyrazine content of Harmonia axyridis Pallas (Coleoptera: Coccinellidae). - J. Chem. Ecol. 38: 854-864.

LuCAs E., Coderre D. \& Vincent C. 1997: Voracity and feeding preferences of two aphidophagous coccinellids on Aphis citricola and Tetranychus urticae. - Entomol. Exp. Appl. 85: 151-159.

Michaud J.P. 2000: Development and reproduction of ladybetles (Coleoptera: Coccinellidae) on the citrus aphids Aphis spiraecola Patch and Toxoptera citricida (Kirkaldy) (Homoptera: Aphididae). — Biol. Control 18: 287-297.

Nedved O. \& Salvucci S. 2008: Ladybird Coccinella septempunctata (Coleoptera: Coccinellidae) prefers toxic prey in laboratory choice experiment. - Eur. J. Entomol. 105: 431-436.

OmKar G.M. \& Srivastava S. 2003: Influence of six aphid prey species on development and reproduction of a ladybird beetle, Coccinella septempunctata. - BioControl 48: 379-393.

O’NeIL R. 1997: Functional response and search strategy of Podisus maculiventris (Heteroptera: Pentatomidae) attacking Colorado potato beetle (Coleoptera: Chrysomelidae). - Environ. Entomol. 26: 1183-1190.

Pervez A. \& OMKar G.M. 2006: Ecology and biological control application of multicoloured Asian ladybird, Harmonia axyridis: A review. - Biocontr. Sci. Techn. 16: 111-128.

Pickering G., Ker K. \& Soleas G. 2007: Determination of the critical stages of processing and tolerance limits for Harmonia axyridis for "ladybug taint" in wine. Vitis 46: 85-90.

Powell K. 2008: Grape phylloxera: An overview. In Johnson S.N. \& Murray P.J. (eds): Root Feeders: An Ecosystem Perspective. CAB International, Wallingford, pp. 96-114.

REZNIK S.Y. \& VAghina N.P. 2011: Photoperiodic control of development and reproduction in Harmonia axyridis (Coleoptera: Coccinellidae). - Eur. J. Entomol. 108: 385-390.

Seko T. \& Miura K. 2008: Functional response of the lady beetle Harmonia axyridis (Pallas) (Coleoptera: Coccinellidae) on the aphid Myzus persicae (Sulzer) (Homoptera: Aphididae). - Appl. Entomol. Zool. 43: 341-345.

Specty O., Febvay G., Grenier S., Delobel B., Piotte C., Pegeaux J.F., Ferran A. \& Gulllaud J. 2003: Nutritional plasticity of the predatory ladybeetle Harmonia axyridis (Coleoptera: Coccinellidae): Comparison between natural and substitution prey. - Arch. Insect Biochem. 52: 81-91.

Steward L.A., Hemptinne J.-L. \& Dixon A.F.G. 1991: Reproductive tactics of ladybird beetles: relationships between egg size, ovariole number and developmental time. - Funct. Ecol. 5: 380-385.

Ungerova D., Kalushkov P. \& Nedved O. 2010: Suitability of diverse prey species for development of Harmonia axyridis and the effect of container size. - IOBC/WPRS Bull. 58: $165-174$.

Xue Y., Bahlai C., Frewin A., Sears M., Schaafsma A. \& HalLETT R. 2009: Predation by Coccinella septempunctata and Harmonia axyridis (Coleoptera: Coccinellidae) on Aphis glycines (Homoptera: Aphididae). - Environ. Entomol. 38: 708-714.

Received April 17, 2012; revised and accepted August 24, 2012 